\title{
Kınanın Gizli Özneleri: Sağlık Söylemleri Altında Yatan Duyuların Belleği *
}

Hidden Subjects of Henna: Health Discourses Underlying the Memory of the Senses

Gözde Dalan Polat ${ }^{i}$

'Dr. Öğr. Üyesi, Yeditepe Üniversitesi, İletişim Fakültesi, Halkla İlişkiler ve Tanıtım Bölümü https://orcid.org/0000-0003-3548-2081

Lokman Hekim Dergisi, 2020; 10 (1): 124-137 DOI: 10.31020/mutftd.650931 ile basılan makalenin 134. sayfasının 7. paragrafının 5. satırındaki "dilimin sınırları dünyamın sınırları değildir"33 cümlesinde yazan "değildir" ibaresi kaynakta yer alan anlam farklılığından dolayı yazar tarafından aşağıda belirtilen şekilde düzeltilmiştir.

\section{Gözde Dalan Polat tarafından yapılan düzeltme}

Genel olarak katılımcılarımla yapmış olduğum görüşmelerde kına-sağlık ilişkisi bağlamında yapmış olduğumuz konuşmalar, onları çocukluk döneminde anneanne ya da babaanne ile geçirmiş oldukları zamanın ruhuna götürmüştür. Derinlemesine yapmış olduğumuz bazı sohbetlerde gerek duraklamalar, gerek kullanılan ses tonları ve gerekse yüz mimikleri kına ile ilgili söylenen sözlerden daha güçlü bir etki bırakmıştır. Bu bize, Wittgenstein’ın “dilimin sınırları dünyamın sınırlarıdıı”33 cümlesini hatırlatmaktadır.

Kaynak

33. Wittgenstein, L.. Tractatus Logico Philosophicus. London: Routledge, 2004

Makalenin erişim adresi:

https://dergipark.org.tr/en/pub/mutftd/issue/51847/650931

*Lokman Hekim Dergisi, 2020; 10 (2): 281

DOI: 10.31020/mutftd.707166

e-ISSN: 1309-8004

Geliş Tarihi - Received: 25 Kasım 2019; Kabul Tarihi - Accepted: 28 Aralık 2019; Düzeltme -Correction: 27 Mart 2020

Iletişim - Correspondence Author: Gözde Dalan Polat<gdalan@yeditepe.edu.tr> 